\title{
Development and Field Evaluation of Multiple Virus-Resistant Bottle Gourd (Lagenaria siceraria)
}

K.-S. Ling and A. Levi, United States Department of Agriculture-Agricultural Research Service (USDA-ARS), U.S. Vegetable Laboratory, Charleston, SC 29414; S. Adkins, USDA-ARS, U.S. Horticultural Research Laboratory, Ft. Pierce, FL 34945; C. S. Kousik, USDA-ARS, U.S. Vegetable Laboratory; G. Miller, Edisto Research \& Education Center, Clemson University, Blackville, SC 29817; and R. Hassell and A. P. Keinath, Coastal Research \& Education Center, Clemson University, Charleston, SC 29414

\begin{abstract}
Ling, K.-S., Levi, A., Adkins, S., Kousik, C. S., Miller, G., Hassell, R., and Keinath, A. P. 2013. Development and field evaluation of multiple virusresistant bottle gourd (Lagenaria siceraria). Plant Dis. 97:1057-1062.

In an effort to develop bottle gourd (Lagenaria siceraria) as a widely adapted rootstock for watermelon grafting, we sought to identify lines with broad resistance to several cucurbit viruses that are economically important in the United States. Preliminary analysis under greenhouse conditions indicated that the currently available commercial watermelon rootstocks were either highly susceptible or somewhat tolerant to one or more viruses. However, in greenhouse screening, several

four viruses tested, including Zucchini yellow mosaic virus, Watermelon mosaic virus (WMV), Papaya ringspot virus watermelon strain (PRSV-W), and Squash vein yellowing virus. Resistance to PRSV-W and WMV was confirmed through field trials in two consecutive years at two different locations in South Carolina. Two breeding lines (USVL\#1-8 and USVL\#5-5) with broad-spectrum virus resistance could be useful materials for watermelon rootstock development.
\end{abstract} breeding lines of bottle gourd displayed broad-spectrum resistance to
Watermelon (Citrullus lanatus (Thunb.) Matsum. \& Nakai var. lanatus), an important vegetable-like fruit, is widely grown around the world. China, with 56.6 million metric tons in 2010, is the world leader in watermelon production. The United States ranks fifth, with 1.9 million metric tons in 2010 (12). The warm and humid conditions that are suitable for watermelon production are also conducive for plant disease development (53). There are at least 39 viruses infecting watermelon and other cucurbit crops $(3,24,38)$. Among them, several aphid-transmitted potyviruses, including Papaya ringspot virus watermelon strain (PRSV-W), Watermelon mosaic virus (WMV), and Zucchini yellow mosaic virus (ZYMV), are prevalent on cucurbit crops throughout the world $(23,24)$. These potyviruses are efficiently spread in fields by more than 10 different aphid species $(4,19,31)$. Under field conditions, mixed infections of multiple viruses are common $(3,45,46)$. In the United States, these cucurbit-infecting viruses have been reported in many cucurbit-growing states $(3,7,9,17,34,38,39$, 45,47), including South Carolina (42). Additionally, a whiteflytransmitted ipomovirus (family: Potyviridae), named Squash vein yellowing virus (SqVYV), has been identified to cause watermelon vine decline in Florida (1).

Although viral diseases are not easy to control, the use of disease resistant cultivars is one of the most effective disease management strategies. Over the years, considerable efforts have been devoted to identify watermelon germplasm that is resistant to several potyviruses $(6,14,43,50)$ and SqVYV $(21)$. However, traditional plant breeding can take years of efforts to develop a new

Corresponding author: K.-S. Ling, E-mail: kai.ling@ars.usda.gov

Mention of a trademark name or proprietary product does not constitute a guarantee or warranty of the product by the USDA-ARS, or Clemson University, nor does it imply exclusion of other products that may be suitable.

Accepted for publication 14 January 2013.

http://dx.doi.org/10.1094/PDIS-07-12-0639-RE

This article is in the public domain and not copyrightable. It may be freely reprinted with customary crediting of the source. The American Phytopathological Society, 2013. cultivar with durable resistance and desirable horticultural characteristics (36,37). Development and application of a molecular marker linking a viral disease resistance locus (loci) would facilitate the breeding process $(15,29)$. Nevertheless, there is still no commercially available virus-resistant watermelon cultivar. Despite the successful development of virus-resistant transgenic watermelon and a rootstock $(28,35,52)$, field application is hampered by consumer resistance to genetically modified food (33). Grafting has become an important part of vegetable production in many Asian countries to manage biotic agents and abiotic stresses $(25,26)$. With the phase-out of methyl bromide fumigation, watermelon grafting is being used as an alternative for disease management in other parts of the world $(8,11)$. In the United States, there is interest in the use of grafted watermelon to combat soilborne and foliar diseases $(10,20,22,44)$.

One of the important factors in the development of widely adapted rootstocks is to incorporate viral disease resistance. In a previous study, we identified a number of accessions with resistance to ZYMV by evaluating the entire United States Department of Agriculture (USDA) bottle gourd (Lagenaria siceraria L.) germplasm collection (30). The objective of the current study was to evaluate several selected breeding lines in the greenhouse for their broad-spectrum resistance against four economically important viruses (PRSV-W, WMV, ZYMV, and SqVYV) and to evaluate their field performance in separate locations in South Carolina.

\section{Materials and Methods}

Seed and plant materials. Seed of 16 cucurbit rootstocks, including seven $L$. siceraria, eight $C$ ucurbita moschata $\times$ C. maxima hybrids, and one wild watermelon (Citrullus lanatus var. citroides), were kindly provided by various seed companies (Fig. 1). Selected breeding lines with ZYMV-resistance (30), designated as U.S. Vegetable Laboratory (USVL) numbers 1 to 9, were self-pollinated to generate seed that could be used for screening in subsequent generations (up to four generations). Two other lines (USVL \#6-3 and \#7-1) were $F_{1}$ hybrids and USVL\#8 was an $F_{2}$ population. A small number of $F_{2}$ plants was tested with the intent to show a segregation of resistance to different viruses; they were not intended for genetic analysis. In some cases, USVL\#10 derived from PI 181948 was used as a virus-susceptible control. For each experi- 
ment, 10 to 15 seeds per line were germinated in Metro Mix 360 potting soil (Sun Gro Horticulture) supplemented with a slow-release fertilizer (Osmocote 14N-14P-14K; Scotts MiracleGro). Seedlings at the one- to two-leaf stages were mechanically inoculated with the test virus.

Virus cultures. Both PRSV-W and WMV isolates were collected from local watermelon fields in Charleston, SC. The ZYMV (39) and SqVYV (1) isolates were collected from diseased watermelon and squash plants in Florida, respectively. Virus cultures were maintained on squash (Cucurbita pepo) 'Early Yellow Crookneck' or watermelon 'Charleston Gray' and transferred to new plants, when necessary, through mechanical inoculation. To confirm broad resistance to two or more viruses, naturally infected leaves collected from fields in Charleston, SC containing both PRSV-W and WMV, as determined by virus-specific enzyme-linked immunosorbent assay (ELISA), were also used for plant inoculations.

Greenhouse evaluation and selection for multiple virus resistant bottle gourd lines. Evaluations for multiple virus resistance on commercial watermelon rootstocks or breeding lines were conducted in a greenhouse in Charleston, SC, against three major cucurbit potyviruses (PRSV-W, WMV, and ZYMV). Due to the limited geographical distribution of SqVYV, evaluation of the selected $L$. siceraria lines for SqVYV resistance was made in a greenhouse in Ft. Pierce, FL. For line USVL\#1 (a parental line to USVL \#1-5 and \#1-8), the number of seedlings used was from 5 to 32; for line USVL\#2, from 5 to 23 ; for line USVL\#3, from 3 to 11 ; for line USVL\#4, from 3 to 8; for line USVL\#5-5, from 3 to 20; for line USVL\#6-3, from 6 to 9; for line USVL\#7-1, from 4 to 25; for line USVL\#8, from 2 to 37; and for line USVL\#9, from 6 to 20. Two commercial rootstock cultivars used to graft watermelon, 'Emphasis' and 'Macis', were used as controls. For 'Emphasis', the number of seedlings screened was 5 to 15 and, for 'Macis', 6 to 30. Because the same lines were tested for resistance to ZYMV in our previous study (30), only one additional ZYMV screening experiment was conducted in the current study. Similarly, one experiment was performed for SqVYV. For PRSV, two screening experiments were done. For WMV, three independent experiments were conducted. Virus inoculum (PRSV-W, WMV, or ZYMV) was prepared by macerating freshly harvested leaf tissue (1:5 [wt/vol]) with a Homex-6 tissue homogenizer (BioReba) in ice-cold $0.01 \mathrm{M}$ phosphate-buffered saline, $\mathrm{pH}$ 7.4. Seedlings dusted with Carborundum (600 mesh) were inoculated by gently rubbing the cotyledons and first true leaf with a cotton swab soaked in freshly prepared virus inoculum. After inoculation, excess Carborundum was removed by rinsing with water. The test seedlings were placed under shade for a few hours to maximize virus infectivity and minimize damage to the inoculated leaves. Inoculum for SqVYV was prepared as previously described $(1,21)$. To minimize potential escapes in inoculation, a follow-up inoculation was carried out within seven days after the first inoculation. In each inoculation experiment, control plants, including virus-susceptible $L$. siceraria USVL\#10; watermelon 'Charleston Gray', 'New Hampshire Midget', or 'Crimson Sweet'; or squash 'Early Yellow Crookneck' were inoculated to ensure that the virus remained infective throughout the inoculation process. Inoculated plants were maintained in a temperature-controlled greenhouse $\left(23\right.$ to $\left.28^{\circ} \mathrm{C}\right)$, and symptom development was monitored 4 to 8 weeks after inoculation. To confirm virus infection, leaf tissues were tested using appropriate laboratory techniques, as described below.

Virus detection. To check for the presence of ZYMV, WMV, and PRSV-W, leaf tissues were sampled 4 weeks post inoculation, and a double-antibody sandwich ELISA was conducted using an antibody specific to each virus according to the manufacturer's instructions (BioReba). Briefly, microtiter plates were coated with $100 \mu \mathrm{l}$ of $1 \mu \mathrm{g} / \mathrm{ml}$ of a virus-specific antibody. Leaf tissue was processed in the tissue extraction buffer $(1: 20[\mathrm{wt} / \mathrm{vol}])$ with a Homex-6 tissue homogenizer (BioReba), and $100 \mu \mathrm{l}$ of tissue extract was loaded in duplicated wells. After incubation at $37^{\circ} \mathrm{C}$ for 3 $\mathrm{h}$, a properly prepared alkaline phosphatase conjugated virus-specific antibody $(1: 1,000)$ was added to the washed plate. Upon incubation with the substrate solution, color development was measured with an ELISA reader (SpectraMax Plus; Molecular Devices). An absorbance value greater than twice that of the mean healthy control (optical density at $405 \mathrm{~nm}$ ) was considered positive. To check for the presence of SqVYV, tissue blot nucleic acid hybridization with a SqVYV coat protein (CP) probe was initially used to test all $L$. siceraria plants as previously described for watermelon (45). In some cases, reverse-transcription polymerase chain reaction (RT-PCR) testing using SqVYV CP gene primers and total plant RNA was used for confirmation, as previously described (2).

Field evaluations. Field trials were performed in two consecutive years (2007 and 2008) in South Carolina. In 2007, field experiments were conducted in two separate locations; the Clemson University Coastal Research and Education Center in Charleston, SC

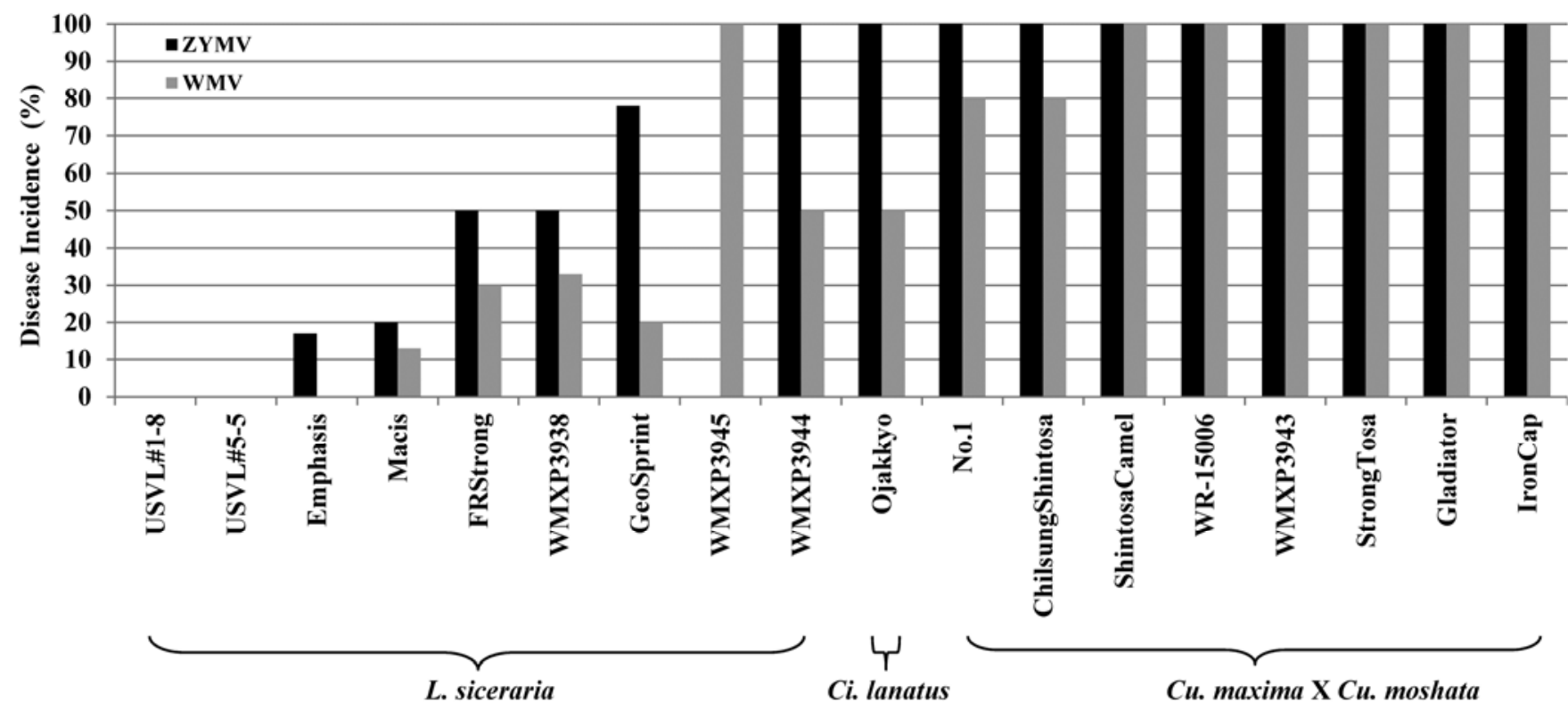

Fig. 1. Incidence of virus infection of commercial watermelon rootstocks upon mechanical inoculation and two newly selected bottle gourd lines (U.S. Vegetable Laboratory \#1-8 and \#5-5) under greenhouse conditions. Lagenaria siceraria: 'Emphasis' (Syngenta), 'Macis' (Nunhems), 'FR Strong' (Seminis), 'Geo Sprint' (Sakata), 'WMXP3938,' 'WMXP3944', and 'WMXP3945' (Harris Moran); Citrullus lanatus var. citroides: 'Ojakkyo' (Syngenta); and Cucurbita moschata × C. maxima hybrids: 'No.1' (Sakata), 'Chilsung Shintosa' (Seminis), 'Shintosa Camel' (Nunhems), 'WR-15006' (Zeraim Gedera), 'Strong Tosa' (Syngenta), 'Iron Cap' (Sakata), 'Gladiator', and 'WMXP3943' (Harris Moran). 
(Charleston) and the Edisto Research and Education Center in Blackville, SC (Blackville). Four potentially virus-resistant lines of bottle gourd-designated as USVL\#1-5 (an S2 offspring derived from a ZYMV-resistant plant of USVL\#1 through self-pollination), USVL\#1-8 (a different sister line derived from USVL\#1 plant with resistance to ZYMV), USVL\#6-3, and USVL\#7-1 were selected for evaluation. A commercial L. siceraria rootstock (Emphasis) and a known virus-susceptible line (USVL\#10) were included as controls. Seed were sown on 6 July 2007 in a greenhouse, and 2- to 3 -week-old seedlings were transplanted at Blackville on 20 July 2007 and at Charleston on 25 July 2007. Any missing plants, due to mortality in the first week after transplanting, were replaced with new seedlings of the same line. The experimental design at each location was a randomized complete block with three replications and five plants per plot. The Blackville site was a single-row raised bed in the middle of a field surrounded by other experimental cucurbit plants of watermelon, squash, and pumpkin. These early crop cucurbit plants were heavily infected with viruses (i.e., they showed mosaic and leaf deformation, and ELISA tests confirmed the presence of PRSV and WMV), which served as initial sources of virus inoculum for the tested bottle gourd plants. Thus, this location was considered to have high virus pressure. In addition, plants of the susceptible control line USVL\#10 displayed mosaic symptoms typical of a virus infection 17 days post transplanting and, by the fourth week, all 15 plants of USVL\#10 in three replications were infected. In comparison, the virus pressure at the Charleston field trial site was lower. This experimental field was located in a relatively isolated area surrounded by a natural tree buffer, away from other virus-infected cucurbit crops. Thus, sources of the initial virus inoculum and the available aphid population were likely lower. Each plot was a single row $3 \mathrm{~m}$ long with $3 \mathrm{~m}$ of open space between plots in the same row. Normal horticultural practices, including watering, fertilization, and a spray program, were followed. Fungicides were applied weekly for several weeks after transplanting to prevent development of downy mildew and powdery mildew.

Plants were observed weekly for viral disease occurrence and progression. Two field evaluations, with symptom observation, sample collection, and subsequent lab tests on each plant, were conducted at 1 month and 3 months post transplanting. Appropriate lab tests (ELISA) for PRSV-W, WMV, and ZYMV were used to identify the viruses involved. Resistance was determined based on no symptom expression in the test plants and negative reactions in confirmation tests for the three potyviruses.

Due to the relatively low incidence of virus infection in test plants at the Charleston location in 2007, a follow-up trial was done in 2008 in a different field also at the Clemson University Coastal Research and Education Center in Charleston, SC. To improve the efficiency of virus acquisition and spread, infected squash plants containing PRSV-W and WMV were planted around the testing block as sources of virus inoculum, and the number of natural aphid vectors was increased through elimination of a typical insect spray program. Because test plants in line USVL\#1-5 were segregating for resistance in the 2007 field trial, this line was eliminated from the 2008 test. In addition to the three original lines (USVL numbers 1-8, 6-3, and 7-1) tested in 2007, six other lines (USVL numbers 2, 3, 4, 5-5, 8, and 9) were also included along with the susceptible control USVL\#10. A randomized complete block design was used with three replications of five plants per plot, as in 2007. Test plants were transplanted on 24 June 2008. Field evaluations were done as in 2007. The percentages of infected plants from each of the field experiments conducted in Blackville in 2007 and Charleston in 2007 and 2008 were arcsine transformed and analyzed using GLM procedure of SAS V.9.1 for Windows (SAS Institute Inc.). Treatment means were separated using Fisher's protected least significant difference $(\alpha=0.05)$.

\section{Results}

Assessing virus resistance in commercial rootstocks. To assess virus resistance in selected commercial rootstocks and newly developed breeding lines, two potyviruses (ZYMV and WMV) were initially used to inoculate seedlings (in a range of 8 to 11 plants per line in each individual virus test) in a greenhouse. Although Citrullus rootstock 'Ojakkyo' and seven Cucurbita rootstocks were fully susceptible to both viruses, various rates of infection, ranging from 13 to $100 \%$, were observed on seven $L$. siceraria rootstocks. Although 'Emphasis' had complete resistance to WMV (Fig. 1), a low percentage of test plants (17\%) was infected by ZYMV. For 'Macis', the resistance to ZYMV and WMV was not complete; a small proportion of test plants (20\% for ZYMV and $13 \%$ for WMV) were susceptible. In both 'FR Strong' and 'WMXP3938,' 50\% of the test plants were susceptible to ZYMV but only 30 to $33 \%$ of them were infected by WMV, respectively. In 'Geo Sprint', $78 \%$ of seedlings were susceptible to ZYMV and only $20 \%$ of them were also infected by WMV. 'WMXP3945' was resistant to ZYMV but was fully susceptible to WMV. Although 'WMXP3944' was fully susceptible to ZYMV, only $50 \%$ of the test plants were infected by WMV. In comparison, two USVL selections (numbers 1-8 and 5-5) exhibited complete resistance to both ZYMV and WMV (Fig. 1).

Greenhouse evaluation of bottle gourd lines against multiple viruses. Because the current commercial bottle gourd rootstocks were either susceptible or not completely resistant to multiple viruses, efforts were initiated to develop bottle gourd lines with broad-spectrum virus resistance. The two most promising commercial $L$. siceraria-based rootstocks ('Emphasis' and 'Macis') had incomplete resistance (a segregating population with a portion of plants resistant and others susceptible to virus infection) against ZYMV, PRSV-W, and WMV. Three USVL lines (USVL numbers 3,4 , and 5-5) and two $F_{1}$ hybrids (USVL numbers 6-3 and 7-1) had complete resistance to these three potyviruses (Table 1). Four other lines (USVL numbers 1, 2, 8, and 9) had incomplete resistance or were segregating for resistance to one or more viruses. In each experiment, susceptible control plants, either Charleston Gray or Crimson Sweet watermelon or L. siceraria USVL\#10, were fully susceptible to virus infection, indicating that virus infectivity in the inoculum was maintained active throughout the inoculation process.

In two lines, USVL \#1-8 and \#5-5, the asymptomatic plants were apparently immune to infection by WMV and ZYMV, as shown by no positive ELISA readings on any of the test plants (Fig. 1). No visible symptoms of SqVYV infection were observed on these USVL lines. Tissue blots of both mock- and SqVYV-inoculated plants of all tested $L$. siceraria lines showed hybridization signals with the SqVYV CP probe (data not shown). However, no SqVYV was detected by RT-PCR testing in any mock-inoculated plants, suggesting that the hybridization signal was likely due to a nonspecific reaction. RT-PCR testing confirmed the presence of SqVYV in pooled total RNA of 'Emphasis' and several USVL lines. No SqVYV was detected by RT-PCR in USVL\#5-5.

Field evaluation for broad-spectrum virus resistance. To verify the observed broad-spectrum resistance to multiple viruses, replicated field trials were conducted in South Carolina in two consecutive years. In the Blackville location, by 7 August 2007, only 17 days post transplanting, the first indication of virus infection, mosaic symptoms, was observed on susceptible control plants (USVL\#10) in all three replicated plots (five plants per plot), indicating that efficient natural virus transmission by aphids had occurred in this field. Based on ELISA tests to three potyviruses, two viruses (PRSV-W and WMV) were prevalent in Blackville, and a mixed infection of these two viruses was common, whereas ZYMV was not detectable in either location in 2007. Results showed that, although USVL\#1-5 was not completely resistant to WMV, three other lines tested (USVL numbers 1-8, 6-3, and 7-1) showed complete resistance to PRSV and WMV (Table 2). Because the distribution of SqVYV is generally limited to the southwestern region of Florida (1), there was no monitoring effort for this virus in either 2007 or 2008 field trials in South Carolina. 
Table 1. Evaluation of selected Lagenaria siceraria lines for multiple-virus resistance in the greenhouse

\begin{tabular}{|c|c|c|c|c|c|}
\hline Cultivar or line ${ }^{v}$ & Source of material & ZYMVw $^{\mathbf{W}}$ & PRSV-W W $^{x}$ & $\mathbf{W M V}^{\mathbf{y}}$ & SqVYVz \\
\hline Emphasis & Syngenta & $0 / 9$ & $1 / 18$ & $2 / 28$ & $2 / 8$ \\
\hline Macis & Nunhems & $2 / 10$ & $2 / 13$ & $7 / 23$ & $0 / 13$ \\
\hline USVL\#1 & PI 271360 & $4 / 14$ & $0 / 11$ & $5 / 27$ & $0 / 11$ \\
\hline USVL\#2 & PI 368635 & $6 / 19$ & $0 / 19$ & $5 / 22$ & $0 / 15$ \\
\hline USVL\#3 & PI 381825 & $0 / 1$ & $0 / 32$ & $0 / 33$ & $0 / 3$ \\
\hline USVL\#4 & PI 381831 & $0 / 5$ & $0 / 20$ & $0 / 20$ & $0 / 3$ \\
\hline USVL\#5-5 & PI 381834 & $0 / 2$ & $0 / 4$ & $0 / 34$ & $0 / 12$ \\
\hline USVL\#6-3 & PI $381825 \times$ PI 368635 & $0 / 5$ & $0 / 14$ & $0 / 17$ & $0 / 8$ \\
\hline USVL\#7-1 & PI $381834 \times$ PI 381825 & $0 / 16$ & $0 / 17$ & $0 / 25$ & $0 / 11$ \\
\hline USVL\#8 & PI $181948 \times$ PI 381831 & $9 / 21$ & $2 / 16$ & $4 / 22$ & $0 / 2$ \\
\hline USVL\#9 & PI 271353 & $0 / 15$ & $0 / 16$ & $0 / 24$ & $\ldots$ \\
\hline
\end{tabular}

${ }^{\vee}$ U.S. Vegetable Laboratory (USVL)\#1 is a parent line (S1) where two sister lines (USVL\#1-5 and USVL\#1-8) were derived through self pollination of each individual Zucchini yellow mosaic virus (ZYMV)-resistant plants. Data on greenhouse screening of USVL\#1-8 plants for resistance to ZYMV and WMV are presented in Figure 1. USVL\#8 was an $\mathrm{F}_{2}$ population derived from a cross between a ZYMV-susceptible plant of PI 181948 (parental line for USVL\#10) $\times$ a ZYMV-resistant plant of PI 381831 (parent line for USVL\#4).

${ }^{w}$ Number of diseased plants per total plants inoculated with ZYMV presented here is based on a single experiment with symptom observation and confirmation by ZYMV-specific enzyme-linked immunosorbent assay (ELISA) test. The low number of seedlings tested in lines number 3 and 5 in this experiment was due to poor germination. These results were in agreement with the results obtained in our previous study (30).

${ }^{\mathrm{x}}$ Combined data from two independent experiments for Papaya ringspot virus watermelon strain (PRSV-W) screening are presented, because similar results were obtained in both experiments. Confirmation of virus infection was determined by testing tissues from upper noninoculated leaves from each plant using a PRSV-W-specific ELISA kit (BioReba).

y Combined data from three independent experiments for Watermelon mosaic virus (WMV) are presented. Similar results were obtained in all of the experiments. Confirmation of virus infection was based on testing leaf tissue from each plant using a WMV-specific ELISA kit (BioReba).

${ }^{\mathrm{z}}$ Data for reaction to Squash vein yellowing virus (SqVYV) are based on the number of symptomatic plants per total number of plants inoculated. All of the watermelon plants used as controls in this experiment were symptomatic and died due to SqVYV-caused watermelon vine decline (data not presented).

Table 2. Assessing resistance of bottle gourd (Lagenaria siceraria) lines to Papaya ringspot virus watermelon strain (PRSV-W) and Watermelon mosaic virus (WMV) in field trials conducted in Blackville and Charleston, SC in 2007

\begin{tabular}{|c|c|c|c|c|c|}
\hline \multirow[b]{3}{*}{ Line } & \multirow[b]{3}{*}{$N^{\mathbf{z}}$} & \multicolumn{4}{|c|}{ Infected plants (\%) at 3 months post transplantingy } \\
\hline & & \multicolumn{2}{|c|}{ Blackville } & \multicolumn{2}{|c|}{ Charleston } \\
\hline & & PRSV-W & WMV & PRSV-W & WMV \\
\hline USVL\#1-5 & 15 & $0.0 \mathrm{a}$ & $20.0 \mathrm{a}$ & 0.0 & 0.0 \\
\hline USVL\#1-8 & 15 & $0.0 \mathrm{a}$ & $0.0 \mathrm{~b}$ & 0.0 & 0.0 \\
\hline USVL\#6-3 & 15 & $0.0 \mathrm{a}$ & $0.0 \mathrm{~b}$ & 0.0 & 0.0 \\
\hline USVL\#7-1 & 15 & $0.0 \mathrm{a}$ & $0.0 \mathrm{~b}$ & 0.0 & 0.0 \\
\hline Emphasis & 15 & $13.3 \mathrm{a}$ & $26.7 \mathrm{a}$ & 0.0 & 6.7 \\
\hline USVL\#10 & 15 & $100.0 \mathrm{~b}$ & $100.0 \mathrm{c}$ & 33.0 & 33.0 \\
\hline$P$ value & $\ldots$ & $<0.0001$ & $<0.0001$ & 0.4834 & 0.5683 \\
\hline
\end{tabular}

y Disease incidence was determined on individual test plants based on enzyme-linked immunosorbent assay (ELISA) tests for PRSV-W and WMV. Means followed by the same letter in a column are not significantly different based on Fisher's protected least significant difference $(\alpha=0.05)$.

${ }^{\mathrm{z}}$ Each U.S. Vegetable Laboratory (USVL) line was replicated three times, with 5 plants per replication, for a total of 15 plants at each location. Virus infection in each plant was confirmed using the appropriate ELISA test.

Although natural virus transmission through aphids in Blackville was apparently very efficient, it was relatively poor in Charleston, because only one-third of the test plants ( 5 of 15) in the susceptible control (USVL\#10) were infected by each virus at the conclusion of the field trial 3 months post transplanting in 2007 (Table 2). With low incidence of infection observed for the susceptible control plants, these results were not conclusive. However, a numerically higher rate of virus infection was observed in the susceptible control, whereas the USVL lines were not infected. In the 2008 trial, efficiency of natural virus transmission in Charleston was improved. At the conclusion of that year's field trial, nearly threequarters of the control susceptible plants (USVL\#10) had expressed symptoms resulting from virus infection. Whereas $78.6 \%$ of the test plants (11 of 14) in USVL\#10 were infected with WMV, $35.7 \%$ of them ( 5 of 14 ) were also infected by PRSV-W. An incomplete resistance to WMV was observed in USVL\#2 plants ( 3 of 14 infected by WMV); virus infection was not detected in test plants from eight other lines (USVL numbers 1-8, 3, 4, 5-5, 6-3, 71, 8, and 9) (Table 3).

\section{Discussion}

Resistance to plant viruses, specifically potyviruses, is often inherited recessively (40). Mutations in the eukaryotic translation initiation factors (i.e., eIF4E, eIF(iso)4E, eIF4G or eIF(iso)4G) have resulted in resistance to specific RNA viruses in a number of plant systems $(18,32,41)$. Our earlier study demonstrated that a nonsynonymous mutation in the $\operatorname{eIF}(4 \mathrm{E})$ is associated with the recessive ZYMV resistance in watermelon (29). Although a recessively inherited resistance trait is generally virus or even strain specific, a trait controlled by a dominant gene often leads to a broad-spectrum resistance to multiple viruses (32). Materials with a single dominant gene that are resistant to as many as nine potyviruses have been identified in Phaseolus vulgaris L. (13). In our previous screening of the USDA $L$. siceraria collection (190 accessions) for ZYMV resistance, 36 and 64 accessions had complete or incomplete resistance, respectively (30). In order to fix the resistance, it was necessary to perform single plant selections to obtain a homozygous state for putative resistance alleles. Our preliminary data in analysis of inheritance of virus resistance with a small number of $F_{2}$ plants in USVL\#8 showed segregating for resistance to ZYMV, PRSV-W, and WMV (Table 1). The genetic study to determine the inheritance of such resistance is currently underway. Despite a long cultivation history, only limited genetic and genomic information for bottle gourd is available (51). The advanced selections with broad-spectrum potyvirus resistance (ZYMV, PRSV-W, WMV, and SqVYV) could be valuable materials for genetic inheritance studies, associated molecular marker development, and resistance gene isolation and characterization.

Among several potential cucurbit rootstocks for watermelon, bottle gourd (L. siceraria) is one of the preferred choices 
Table 3. Assessing the resistance of bottle gourd lines to Papaya ringspot virus watermelon strain (PRSV-W) and Watermelon mosaic virus (WMV) infection in field experiments conducted in Charleston, SC in 2008

\begin{tabular}{lccc}
\hline & & \multicolumn{2}{c}{ Infected plants $(\%)^{\mathbf{z}}$} \\
\cline { 3 - 4 } Line & $\boldsymbol{N}$ & PRSV-W & WMV \\
\hline USVL\#1-8 & 15 & 0.0 & $0.0 \mathrm{a}$ \\
USVL\#2 & 14 & 0.0 & $21.4 \mathrm{a}$ \\
USVL\#3 & 15 & 0.0 & $0.0 \mathrm{a}$ \\
USVL\#4 & 15 & 0.0 & $0.0 \mathrm{a}$ \\
USVL\#5-5 & 15 & 0.0 & $0.0 \mathrm{a}$ \\
USVL\#6-3 & 15 & 0.0 & $0.0 \mathrm{a}$ \\
USVL\#7-1 & 15 & 0.0 & $0.0 \mathrm{a}$ \\
USVL\#8 & 15 & 0.0 & $0.0 \mathrm{a}$ \\
USVL\#9 & 15 & 0.0 & $0.0 \mathrm{a}$ \\
USVL\#10 & 14 & 35.7 & $78.6 \mathrm{~b}$ \\
$P$ value & $\ldots$ & 0.4825 & 0.0002 \\
\hline
\end{tabular}

${ }^{\mathrm{z}}$ Disease incidence was determined on individual test plants based on enzyme-linked immunosorbent assay tests for PRSV-W and WMV. For WMV, means followed by the same letter in a column are not significantly different based on Fisher's protected least significant difference $(\alpha=0.05)$. For PRSV-W, a numerically higher rate of virus infection was observed in the susceptible control USVL\#10 compared with other U.S. Vegetable Laboratory (USVL) lines which were not infected. However, the differences were not significant.

$(8,10,11,20)$. However, initial evaluations in the greenhouse demonstrated that commercial rootstocks were susceptible or had incomplete resistance to ZYMV and WMV. An increased tolerance to viral disease infection has been reported in grafted seedless watermelon compared with the nongrafted control but the mechanism is still elusive (48). Such increased tolerance to viral disease in the field was also observed in a trial (2007) in Charleston, SC, though the specific virus involved was not determined using lab tests (R. Hassell, personal communication). However, in other studies, grafting susceptible scions onto virus-resistant rootstocks (including USVL\#1-8 and USVL\#5-5) was not effective in preventing SqVYV-induced watermelon vine decline (49). An increased susceptibility in grafted cucumber or watermelon plants to virus infection has also been demonstrated, although the mechanism for the increased susceptibility of grafted plants to virus infection has yet to be understood $(5,16)$. Grafted plants could be incompatible or potentially be infected by seedborne viruses during the grafting process (10).

Information about the genetic diversity among bottle gourd germplasm with respect to disease or pest resistance is still lacking. Levi et al. (27) used DNA markers to evaluate genetic differences among many bottle gourd accessions for disease resistance and determined that accessions originally collected from the same geographical region shared a similar genetic background. A number of accessions collected in Southern Asia (India), including the ones used in the development of the USVL lines in the current study, were resistant to several important viruses and other fungal diseases (27), whereas other accessions collected in South and Central America were less susceptible to root-knot nematode $(27,43)$. With the germplasm for virus and other disease resistance identified, it is now possible for plant breeders to develop superior bottle gourd varieties with durable resistance to multiple diseases and pests.

\section{Acknowledgments}

We thank M. Farnham and A. Simmons of USDA-ARS, U.S. Vegetable Laboratory for critical readings and valuable comments to the manuscript; and A. Gilliard, G. DuBose, E. Fillippeli, and C. Vanderspool for their excellent technical assistance.

\section{Literature Cited}

1. Adkins. S., Webb, S. E., Achor. D., Roberts, P. D., and Baker, C. A. 2007. Identification and characterization of a novel whitefly-transmitted member of the family Potyviridae isolated from cucurbits in Florida. Phytopathology 97:145-154.

2. Adkins, S., Webb, S. E., Baker, C. A., and Kousik, C. S. 2008. Squash vein yellowing virus detection using nested polymerase chain reaction demonstrates that the cucurbit weed Momordica charantia is a reservoir host. Plant
Dis. 92:1119-1123.

3. Ali, A., Mohammad, O., and Khattab, A. 2012. Distribution of viruses infecting cucurbit crops and isolation of potential new virus-like sequences from weeds in Oklahoma. Plant Dis. 96:243-248.

4. Blackman, R. L., and Eastop, V. F. 2000. Aphids of the World's Crops: An Identification and Information Guide, 2nd ed. John Wiley \& Sons, London.

5. Boubourakas, I. N., Harziloukas, E., Antignus, Y., and Katis, N. I. 2004. Etiology of leaf chlorosis and deterioration of the fruit interior of watermelon plants. J. Phytopathol. 152:580-588.

6. Boyhan G., Norton J. D., Jacobsen, B. J., and Abrahams, B. R. 1992. Evaluation of watermelon and related germplasm for resistance to zucchini yellow mosaic virus. Plant Dis. 76:251-252.

7. Chala, V. H., Harrison, C. W., and Halliwell, R, S. 1987. Identification of two strains of watermelon mosaic virus 2 affecting cucurbits in Texas. Plant Dis. 71:750-752.

8. Cohen, R., Burger, Y., Horev, C., Koren, A., and Edelstein, M. 2007. Introducing grafted cucurbits to modern agriculture an Israeli experience. Plant Dis. 91:916-923.

9. Davis, R. E., and Mizuki, M. K. 1987. Detection of cucurbit viruses in New Jersey. Plant Dis. 71:40-44.

10. Davis, A. R., Perkins-Veazie, P., Sakata, Y., Lopez-Galarza, S., Maroto, J. V., Lee, S.-G., Huh, Y.-C., Sun, Z., Miguel, A., King, S. R., Cohen, R., and Lee, J.-M. 2008. Cucurbit grafting. Crit. Rev. Plant Sci. 27:50-74.

11. Edelstein, M. 2004. Grafting vegetable-crop plants: pros and cons. Acta Hortic. 659:235-238.

12. FAOSTAT, Food and Agriculture Organization of the United Nations, 2010.

13. Fisher, M. L., and Kyle, M. M. 1994. Inheritance of resistance to potyviruses in Phaseolus vulgaris L. III. Cosegregation of phenotypically similar dominant responses to nine potyviruses. Theor. Appl. Genet. 89:818-823.

14. Gillaspie, A. G., and Wright, J. M. 1993. Evaluation of Citrullus sp. germplasm for resistance to watermelon mosaic virus 2. Plant Dis. 77:352 354.

15. Harris, K. R., Ling, K.-S., Wechter, W. P., and Levi, A. 2009. Identification and utility of markers linked to the Zucchini yellow mosaic virus resistance gene in watermelon. J. Am. Soc. Hortic. Sci. 134:1-6.

16. Iwasaki, M., Yamamoto, T., and Inaba, T. 1996. Wilt of cucumber plants grafted on squash rootstocks caused by viruses. Bull. Shikoku Natl. Agric. Exp. Stn. 60:1-88. (In Japanese with English summary)

17. Jossey, S., and Babadoost, M. 2008. Occurrence and distribution of pumpkin and squash viruses in Illinois. Plant Dis. 92:61-68.

18. Kang, B. C., Yeam, I., and Jahn, M. M. 2005. Genetics of plant virus resistance. Annu. Rev. Phytopathol. 43:581-621.

19. Katis, N. I., Tsitsipis, J. A., Lykouressis, D. P., Papapanayotou, A., Kokinis, G. M., Perdikis, D. C., and Manoussopoulos, I. N. 2006. Transmission of Zucchini yellow mosaic virus by colonizing and noncolonizing aphids in Greece and new aphid vectors of the virus. J. Phytopathol. 154:293-302.

20. King, S. R., Davis, A. R., LaMolinare, B., Liu, W., and Levi, A. 2008 Grafting for disease resistance. HortScience 43:1673-1676.

21. Kousik, C. S., Adkins, S., Turechek, W. W., and Roberts, P. D. 2009 Sources of resistance in U.S. plant introductions to watermelon vine decline caused by Squash vein yellowing virus. HortScience 44:256-262.

22. Kousik, C. S., Levi, A., Ling, K.-S., and Wechter, W. P. 2008. Potential sources of resistance to cucurbit powdery mildew in US plant introductions (PI) of bottle gourd. HortScience 43:1359-1364.

23. Lecoq, H., and Desbiez, C. 2008. Watermelon mosaic virus and Zucchini yellow mosaic virus. Pages 433-440 in: Encyclopedia of Virology, Vol. 5, 3rd ed. B. W. J. Mahy and M. H. V. Van Regenmortel, eds. Elsevier, Oxford.

24. Lecoq, H., Wisler, G., and Pitrat, M. 1998. Cucurbit viruses: the classics and the emerging. Pages 126-142 in: Cucurbitaceae '98, Evaluation and Enhancement of Cucurbit Germplasm. J. D. McCreight, ed. ASHS Press, Alexandria, VA.

25. Lee, J.-M. 1994. Cultivation of grafted vegetables I. Current status, grafting methods, and benefits. HortScience 29:235-239.

26. Lee J. M. 2003. Advances in vegetable grafting. Chronica Hortic. 43:13-19.

27. Levi, A., Thies, J., Ling, K.-S., Simmons, A. M., Kousik, C., and Hassell, R. 2009. Genetic diversity among Lagenaria siceraria accessions containing resistance to root-knot nematodes, whiteflies, ZYMV or powdery mildew. Plant Genet. Resour. Characterization Utilization 7:216-226.

28. Lin, C. Y., Ku, H. M., Chiang, Y. H., Ho, H. Y., Yu, T. A., and Jan, F. J. 2012. Development of transgenic watermelon resistant to Cucumber mosaic virus and Watermelon mosaic virus by using a single chimeric transgene construct. Transgenic Res. Online publication. doi:10.1007/s11248-0119585-9588

29. Ling, K.-S., Harris, K. R., Meyer, J. D., Levi, A., Guner, N., Wehner, T. C., Bendahmane, A., and Havey, M. J. 2009. Non-synonymous single nucleotide polymorphisms in the watermelon eIF4E gene are closely associated with resistance to Zucchini yellow mosaic virus. Theor. Appl. Genet. 120:191-200.

30. Ling, K.-S., and Levi, A. 2007. Sources of resistance to Zucchini yellow mosaic virus in Lagenaria siceraria germplasm. HortScience 42:11241126.

31. Lisa, V., Boccardo, G., D’Agostino, G., Dellavalle, G., and D’Aquilio, M 
1981. Characterization of a potyvirus that causes zucchini yellow mosaic. Phytopathology 71:667-672.

32. Maule, A., and Caranta, C., and Boulton, M. 2007. Sources of natural resistance to plant viruses: status and prospects. Mol. Plant Pathol. 8:223-231.

33. Moschini, G., Bulut, H., and Cembalo, L. 2005. On the segregation of genetically modified, conventional and organic products in European agriculture: a multi-market equilibrium analysis. J. Agric. Econ. 56:347-372.

34. Nameth, S. T., Dodds, J. A., Paulus, A. O., and Laemmlen, F. F. 1986. Cucurbit viruses of California: an ever changing problem. Plant Dis. 70:8-11.

35. Park, S. M., Lee, J. S., Jenal, S., Jeon, S. L., Shin, Y. S., Her, N. H., Lee, J. H., Lee, M., Ryu, K. H., Yang, S. G., and Harn, C. H. 2005. Transgenic watermelon rootstock resistant to CGMMV (Cucumber green mottle mosaic virus) infection. Plant Cell Rep. 24:350-356.

36. Provvidenti, R. 1991. Inheritance of resistance to the Florida strain of Zucchini yellow mosaic virus in watermelon. HortScience 26:407-408.

37. Provvidenti, R. 1993. Resistance to Viral Diseases of Vegetables. M. M. Kyle, ed. Timber Press, Portland, OR.

38. Provvidenti, R. 1996. Diseases caused by viruses. Pages 37-45 in: Compendium of Cucurbit Diseases. T. A. Zitter, D. L. Hopkins, and C. E. Thomas, eds. American Phytopathological Society, St. Paul, MN.

39. Provvidenti, R., Gonsalves, D., and Humayden, H. S. 1984. Occurrence of Zucchini yellow mosaic virus in cucurbits from Connecticut, New York, Florida, and California. Plant Dis. 68:443-446.

40. Provvidenti, R., and Hampton, R. O. 1992. Sources of resistance to potyviruses. In: Potyvirus taxonomy. Arch. Virol. (Suppl. 5):189-211.

41. Robaglia, C., and Caranta, C. 2006. Translation initiation factors: a weak link in plant RNA virus infection. Trends Plant Sci. 11:40-45.

42. Sammons, B., Barnett, O. W., Davis, R. F., and Mizuki, M. K. 1989. A survey of viruses infecting yellow summer squash in South Carolina. Plant Dis. 73:401-404.

43. Strange, E. B., Guner, N., Pesic-VanEsbroeck, Z., and Wehner, T. C. 2002.
Screening the watermelon germplasm collection for resistance to Papaya ringspot virus type-W. Crop Sci. 42:1324-1330.

44. Thies, J. A., Ariss, J. J., Hassell, R. L., Olson, S., Kousik, C. S., and Levi, A. 2010. Grafting for management of southern root-knot nematode, Meloidogyne incognita, in watermelon. Plant Dis. 94:1195-1199.

45. Turechek, W. W., Kousik, C. S, and Adkins, S. 2010. Distribution of four viruses in single and mixed infections within infected watermelon plants in Florida. Phytopathology 100:1194-1203.

46. Turechek, W. W., Kousik, C. S., and Adkins, S. 2010. Patterns of virus distribution in single and mixed infections of Florida watermelons. HortScience 45:511-512.

47. Ullman, D. E., Cho, J. J., and German, T. L. 1991. Occurrence and distribution of cucurbit viruses in the Hawaiian Islands. Plant Dis. 75:367-370.

48. Wang, J., Zhang, D. W., and Fang, Q. 2002. Studies on antivirus disease mechanism of grafted seedless watermelon. J. Anhui Agric. Univ. 29:336339.

49. Webster, C. G., Kousik, C. S., Hassell, R. L., Ling, K.-S., Turechek, W. W., and Adkins, S. 2012. Virus movement within grafted watermelon plants. (Abstr.) Phytopathology 102:S4:133.

50. Xu, Y., Kang, D., Shi, Z., Shen, H., and Wehner, T. 2004. Inheritance of resistance to Zucchini yellow mosaic virus and Watermelon mosaic virus in watermelon. J. Hered. 95:498-502.

51. Xu, P., Wu, X., Luo, J., Wang, B., Liu, Y., Ehlers, J. D., Wang, S, Lu, Z., and Li, G. 2011. Partial sequencing of the bottle gourd genome reveals markers useful for phylogenetic analysis and breeding. BMC Genomics 12:467.

52. Yu, T.-A., Chiang, C.-H., Wu, H.-W., Li, C.-M., Yang, C.-F., Chen, J.-H Chen, Y.-W., and Yeh, S.-D. 2011. Generation of transgenic watermelon resistant to Zucchini yellow mosaic virus and Papaya ringspot virus type W. Plant Cell Rep. 30:359-371.

53. Zitter, T. A., Hopkins, D. L., and Thomas, C. E. 1996. Compendium of Cucurbit Diseases. American Phytopathological Society, St. Paul, MN. 